\title{
Innovation and Entrepreneurship in the Hospitality Industry
}

\author{
Cathy A. Enz \\ Cornell University \\ Jeffrey S. Harrison \\ University of Richmond
}

\begin{abstract}
Most hotel companies are in the business of 'selling sleep' to their customers. I teach our staff that we're in the business of 'creating dreams'.
\end{abstract}

(Chip Conley, CEO Joie de Vivre Hotels)

\section{INTRODUCTION}

The hospitality industry has undergone tumultuous changes in the last five years. Competitive pressures, shifting consumer preferences and consumption patterns, technological advances, consolidation, price discounting, and new distribution channels are but a few of the changes in the business landscape. Innovation has been championed as a way to cope with these and other changes in the industry. But what exactly is innovation, how has it functioned in the hospitality industry and what are the key ideas to help foster innovation? The purpose of this chapter is to explore hospitality innovation and the related area of entrepreneurship. Innovation and entrepreneur- ship are connected because the entrepreneurial mindset is essential to founding new businesses as well as rejuvenating existing ones (McGrath and MacMillan, 2000). In this chapter we define innovation and explore how to foster it in hospitality contexts. Entrepreneurship, or the creation of new businesses, is explored in the second portion of this chapter. We focus on the characteristics of entrepreneurs, key issues of concern in start-ups, and franchising as a business form in the hospitality sector. The chapter concludes by offering suggestions for future study of this area. Most of the research referenced in the discussions in this chapter is based on North American conceptualizations of innovation and entrepreneurship and of the activities of North American innovators and entrepreneurs. 
Innovation cannot be separated from a firm's strategy or its competitive environment, which means that what we consider to be innovative is defined by the strategic choices a firm makes and the setting in which the firm operates. Some argue that innovation is the most important component of a firm's strategy because it provides direction for the evolution of a firm (Hamel, 2000; German and Muralidharan, 2001). This view is supported by a variety of studies that have found innovative firms to be higher performers (Grimm and Smith, 1999; Roberts, 1999; Subramaniam and Venkatraman, 1999). Hamel (2000) for example found that CEOs in a wide variety of industries felt that newcomers, not incumbents, had changed their industries primarily by changing the rules. Amit and Zott (2001) find support for this contention in a study of e-businesses in which the introduction of new services and goods (i.e. novelty) was a key driver of value creation.

Other researchers have found that those firms who are first to introduce new goods or services (first movers) are able to gain benefits until competitors imitate (Grimm and Smith, 1999). The concept of the 'Heavenly Bed', first launched by the Westin brand in September of 1999, may be an example of benefit gained by being the first to introduce a product rejuvenation. 'It was inconceivable to me that hotels in the business of selling sleep paid so little attention to their beds', claimed Barry Stemlicht, the then Chairman and CEO of Starwood Hotel and Resorts when he and senior executives first launched the innovation (Hospitality Design, 1999). Starwood transformed a basic good into a luxurious object of desire, in the process spawning a new retail enterprise with sales of over $\$ 1$ million annually and imitators who followed (Sheehan, 2001). Was the new bed really an innovation? If competitors had been providing high quality beds for decades what made this introduction so profitable and innovative? To explore how the industry could consider the offering of a hotel bed as an innovation we first must clarify what innovation means.

\section{What is innovation?}

The invention of a new service, product, process, or idea is often called an innovation. For many invention and innovation are synonymous. However innovation also includes existing ideas that are reapplied or deployed in different settings for different customer groups. The early development of innovation theory by Schumpeter (1934) conceived of innovation as a source of value creation in which novel combinations of resources produced new 
products, production methods, markets or supply sources. Innovations may be a recombination of old ideas or a unique approach that is perceived as new by the individuals involved (Van de Ven et al., 1999). The development of electronic newspapers from around the world delivered to hotel guests on-demand is an example of combining the old idea of providing a copy of a local paper to each guest room with the benefits to be derived from developments in information technology.

Innovation combines invention with commercialization, making it easy to see why innovation and entrepreneurship are so closely linked. Developing a new product or process is not enough; the innovative firm must know how to convert an idea into a service or product that customers want. In many instances the new idea requires the creation of a new business to produce and sell the idea to customers. However, innovation within existing firms is also possible. Returning to the 'Heavenly Bed', as part of the promotional efforts to roll out the new beds USA Today ran a story on the front page of its business section (Enz, 2005). On the same day 20 pristine white 'Heavenly Beds' lined Wall Street up to the New York Stock Exchange in New York City. Inside the Stock Exchange, Stemlicht rang the opening bell and threw out hats proclaiming 'Work like the devil. Sleep like an angel'. Meanwhile, at New York's Grand Central Station 20 more beds graced one of the rotundas, and commuters disembarking the trains were invited to try them out. Similar events were staged that day in 38 locations across the US, tailored to each city. Savannah's event featured a bed floating on a barge down the river, replete with a landing skydiver. Seattle's event took place atop the Space Needle. And to reinforce the message, a concurrent advertising campaign asked: 'Who's the best in bed?' (Sheehan, 2001). In the case of Westin hotels, the commercialization of the innovation was not a new business startup but a successful marketing and public relations campaign.

Firms innovate in a number of ways, including business models, products, services, processes, and marketing channels with the goal of maintaining or capturing markets, or the desire to reduce costs or prices through greater efficiencies (Harrison and Enz, 2005). Starwood appears to have been as clever at marketing the bed as developing the original 'all white' look of the product, raising the possibility that the real innovation was in marketing the bed. Further, the introduction of the all-white 'Heavenly Bed' with a customdesigned pillow-top mattress, goosedown comforters, five pillows and three crisp sheets ranging in thread count from 180 to 250 , was not a radical product innovation. 


\section{Types of innovation}

To understand innovation it is important to realize that it can be characterized into different types depending on the nature of the change in knowledge. Innovations are often characterized as 'radical' when the knowledge required is different from what exists currently versus 'incremental' when the existing knowledge is built-on to enable a new product, service, process, or marketing channel. The 'Heavenly Bed' was an incremental product innovation. In contrast, expanding worldwide communication via the Internet is more likely to yield radical innovations for the hospitality industry and the establishment of new business enterprises. According to Peter Drucker, 'The explosive emergence of the Internet as a major, perhaps eventually the major, worldwide distribution channel for goods, services, and, surprisingly, for managerial and professional jobs is profoundly changing economies, markets, and industry structures; products and services and their flow; consumer segmentation, consumer values, and consumer behavior; jobs and labor markets' (Drucker, 1999: 47). Firms are using the Internet for e-tailing, exchanging data with other businesses, business-to-business buying and selling, and e-mail communications with a variety of stakeholders. Travel is the most successful commercial sector on the Internet, bringing fundamental and radical changes to both airlines and travel agencies. Airlines in particular were aggressive leaders in using the Internet to bypass their product and service intermediaries. With the advent of electronic ticketing in 1995, airlines were able to reduce distribution costs by combining their established national networks and brand awareness with direct Internet sales. Traditional travel agencies began losing sales not only to airline sites but also to online agencies. According to Sabre ${ }^{\circledR}$ (the SemiAutomatic Business Research Environment, a large global distribution system, was the first real-time business application of computer technology in the travel industry, designed in the 1950s through a partnership between American Airlines and IBM, an innovation that transformed the airline industry from handwritten passenger reservation information to an automated system) $15 \%$ of all airline tickets are sold through the Internet, with more than half being sold directly by airline web sites, and the other half from online agencies (National Commission, 2002). Travelers have discovered that they can obtain direct access to information, lower rates, and other benefits (Enz, 2003). Finally, information technologies are changing at such an amazing rate that the Internet is likely to be a source of entrepreneurial ventures for many years to come. In summary, incremental innovations like the 'Heavenly Bed' rely on existing knowledge while the onestop travel services that permit a customer to complete all travel-related activities by visiting one site, such as Travelocity, rely on radical new technologies, new forms of inter-firm cooperative alliances, sophisticated 
Another distinction developed in the innovation literature categorizes innovations as product versus process innovations. Product innovations address final goods or services while process innovations address how an organization does its business. In the first week of Westin's new bed introduction numerous guests called to ask where they could buy the 'Heavenly Bed'. While Westin executives had not anticipated a viable retail business they quickly put order cards with a toll-free number in every room, started placing catalogs by bedsides and desks, and set up a Web site (Guadalupe-Fajardo, 2001). By June of 2004 Westin had sold enough beds on-line to spread the idea throughout Starwood, with the Sheraton (four star), St. Regis (five star) and W (boutique) brands all turning into retailers (Schoenberger, 2004). The use of on-line retailing was a process innovation for getting beds to customers, but also a new product innovation in the form of selling beds and a channel innovation in retailing hotel items. Finally, the 'Heavenly Bed' has spawned new businesses that help hotels run their retail arms. Boxport, a spin-off of San Francisco- based hotel procurer Higgins Purchasing Group, operates Web sites and catalogs for a number of hotel chains (Enz, 2003). In total the simple introduction of a comfortable 'allwhite' bed in a hotel chain has illustrated how just one innovation can incorporate incremental, product, process, marketing, and supply chain innovations in order to move from idea to commercialization.

\section{Fostering innovation}

Several factors seem to encourage innovation according to a variety of studies. Some of the factors that encourage innovation include: a clear vision and culture that supports innovation and risk taking; top management support; teamwork and collaboration; decentralized approval processes; excellent communications; a learning focused innovation orientation; and rewards for successful managers (Harrison and Enz, 2005). In fact a firm's success may rely more on an overall innovation orientation that produces capabilities for innovation and less on specific innovations. The concept of an organizational innovation system or orientation was developed by Siguaw, Simpson and Enz (2006) and is defined as:

A multidimensional knowledge structure composed of a learning philosophy, strategic direction and trans-functional beliefs that guides and directs all organizational strategies and actions, including those embedded in the formal and informal systems, behaviors, competencies, and processes of the firm. 
This orientation promotes innovative thinking and facilitates successful development, evolution, and execution of innovations. Having an orientation toward innovation means developing a pervasive set of understandings about learning, thinking, acquiring, transferring and using knowledge (Siguaw et al., 2006).

In the innovation-orientation framework, strategic direction is the 'way of thinking and leading' that drives the firm over the long run, keeping it innovative, and clear in thought and purpose. The direction is generally articulated through vision and mission statements and objectives. The existing literature suggests that successful innovators tend to have a clearcut, well-supported vision that includes an emphasis on innovation (Quinn, 1985). Their cultures support this vision by encouraging people to discuss new ideas and take risks. The organization not only tolerates failures, but encourages employees and managers to learn from them (Kuratko and Hodgetts, 2001). The cultures of service firms like Disney, Southwest Airlines, Starbuck's and Ben and Jerry's illustrate the importance of having line- level service workers engaged in creating the experience.

Firms that foster an innovation orientation have designed a unique set of structures and guiding principles that determine activities and behaviors in each functional area. The various functional areas of an innovation-oriented firm are guided by a unique, embedded knowledge structure that encourages and facilitates knowledge transfer across and within sub-units. As Sivadas and Dwyer (2000: 33) state, 'Innovators need some mechanism to connect departmental "thought worlds" so that insights possessed by individual departments can be combined to develop new products that harness the collective wisdom of all involved'.

A culture that supports innovation encourages employees and managers to challenge old ideas by instilling a commitment to continuous learning and strategic change. 'Past wisdom must not be a constraint but something to be challenged. Yesterday's success formula is often today's obsolete dogma.' As J. W. 'Bill' Marriott Jr., the CEO of Marriott characterizes his philosophy, 'Success is never final'. He continually stresses three things in articulating his company's values and culture. The first is the constant need to improve, to always try to get better. Second, is the sharing of best practices across brands. Practices that are invented in one part of the company should be shared with everyone in the company. Third, he notes always be looking for new ideas. Customer needs change and competitors improve (Dube et al., 2001). 
Innovation is also more likely to emerge from a company with a culture that values the ideas of every person. Making everyone in an organization responsible for innovation may be one essential way to foster strong innovation cultures according to some experts. As one expert on the topic notes, 'Many companies have succeeded in making everyone responsible for quality. We're going to have to do the same for innovation' (Hamel, 2001: 135). Innovative cultures also promote personal growth in an effort to attract and retain the best people. Joie de Vivre, a small regional hotel company uses a month-long sabbatical program for its salaried employees to reflect and nourish themselves, while Day Hospitality Group provides sabbatical leaves to GMs after five years of service (Conley, 2001; Enz and Siguaw, 2003). The best people also seek ownership, and innovative companies often provide it to them through stock incentives and stock options (Naisbitt and Aburdene, 1985). This is one way to align the interests of the organization with the interests of talented individuals.

Top-management support of innovation is essential, and numerous lodging firms have begun to develop corporate innovation positions or even programs to develop and train employees with regard to innovation and corporate entrepreneurship (Pearce, Kramer and Robbins, 1997). Choice Hotels conducts an annual organization-wide talent review, which includes a mapping of upcoming business initiatives against competency shortfalls by senior executive staff. They use this readiness assessment to determine current leadership capability to pursue new business initiatives (Dube et al., 2001) Because they shape the vision and purpose of the organization, top managers must also serve a disruptive role, making sure that managers and employees don't get too comfortable with the way things are. Richard Branson, CEO of the Virgin Group (including Virgin Airlines), is an excellent example of a CEO that supports innovation. The overall philosophy of the group is to find areas in which Virgin can provide a better service or product to people than they are currently getting (Harrison and Enz, 2005). This philosophy has led the group into a wide variety of hospitality, entertainment, and service businesses.

As top managers support innovation, they also have to be careful not to be too dictatorial in their decision making. Authoritarian management can stifle innovation. This type of management is being replaced by networking, teams and a 'people friendly' style of management (Naisbitt and Aburdene, 1985). At Chowking Food Corporation, an oriental fast-food restaurant, new product development involves almost all key departments, not just the head cooks and the research and development department, 'We are one big team with the president himself heading the product board. All aspects of operations 
are involved', notes Jojo Ajero the marketing manager (Business World Online, 2002).

In addition to top managers, organizational champions are important (Green, Brush and Hart, 1999). A champion is committed to a project and is willing to expend energy to make sure it succeeds. Two champions are needed. The first is a managerial champion, a person with enough authority in the company to gather the resources and push the project through the administrative bureaucracy. The second is a technical champion. This is an expert with the knowledge needed to guide the technical aspects of the project from beginning to end. In a study of best practices in the lodging industry, the importance of an idea champion to foster new practices was revealed in case after case of innovative hotel operators (Dube et al., 2001). The development and successful implementation of hotel level innovations is greatly influenced by just one individual in an organization who believes in, is committed to, and champions the idea or practice (Enz and Siguaw, 2003). Unfortunately, many of these champions are unable to sustain the innovations they begin. The lack of time to think, plan, and develop best practices, and insufficient nurturing of innovations with needed resources and top- management support were identified as barriers to the development of innovations in the lodging industry (Dube et al., 2001).

A follow up analysis to a comprehensive Cornell University study of best practices in the US lodging industry found that many of the champions were no longer working for the same company, and many of the practices they initiated had been discontinued. The high mobility of hospitality managers and the escalating rate of consolidation through mergers and acquisitions were the factors that most influenced the longevity of innovations. Enz and Siguaw (2003) report on one innovator whose departure from his hotel resulted in the best practice being discontinued under the new management, although the practice had been responsible for generating a $20 \%$ increase in occupancy rates and the highest average daily rate (ADR) of all the same branded peer hotels. As idea champions are transferred, or leave the company altogether, the practice is typically not championed by new management and consequently is no longer utilized, regardless of the documented benefits it previously brought the company. As Ali Kasciki, one industry innovator, observed, 'Unfortunately in this industry short- and medium-term versus longterm strategy is the norm. We go in to turn around a problem and then jump to the next position with a better salary' (Enz and Siguaw, 2003: 116). Hotel companies that are wholly absorbed by another organization appeared unable to sustain their best practices in the wave of sweeping managerial, process, and procedural changes. Further, the 
acquiring companies often lack the historical knowledge that provides the roots and benefits of the innovation and thus, makes it difficult for the acquiring company to accept and benefit from past best practices. These results provide disquieting insights into how tenuous innovations in the hospitality industry can be.

Rigid bureaucracies can also stifle innovation. They are characterized by rules, policies, and procedures that make it difficult for an individual to vary from normal activities. People who feel as though they cannot or should not vary from established rules are unlikely to be sources of creativity and innovative thought. McDonald's for example has had to reinvent itself to continue market growth by experimenting with a number of product innovations, acquiring new concepts such as Chipotle Mexican Grill and Boston Market (Restaurant Business, 2002). To maintain an adaptive, learning atmosphere at all organizational levels, many firms have created self-managed work teams and crossfunctional product-development teams, so that multiple perspectives will be brought to problem solving. Teams cut across traditional functional boundaries, so that a single team might include representatives from finance, marketing, information systems, and human resources. These teams are kept small so that they are highly flexible, adaptable, and easy to manage (Quinn, 1985). The management hierarchy in these types of organizations tends to be flat, meaning that there are not a lot of levels in the management hierarchy between the customer and the top manager.

The level at which projects are approved is also a key factor in determining support for innovative activities. Some large corporations require that an idea receive approval from five or more managers before any resources are committed to pursuing it. Innovative organizations allow project teams to form that do not report through the traditional lines of authority.

Consequently, their work does not have to pass through multiple levels for approval. The Ritz-Carlton Tysons Comer for example established an innovative program to shift decision making from management to the hourly staff and eliminate by attrition certain management positions. The initiative began with the executive committee of the hotel changing its name to the 'guidance team', to help set the tone for what it hoped to achieve (Walsh et al., 2003). A mission statement was created and signed by all employees, and special attention was given to keeping everyone, especially the hourly workers fully informed and consulted every step of the way. After considerable discussion, the hotel staff identified a number of management tasks for possible transfer to the hourly staff, including forecasting budgets and work scheduling. The results of this initiative were reductions in 
management costs, lowered employee turnover, increased guest satisfaction, and a more motivated and committed staff (Dube et al., 2001).

Unfortunately, many large companies do not give equal attention to everyone's ideas. They expect senior managers to come up with all of the innovations. Along with an egalitarian culture, excellent communications are found in innovative organizations. They encourage communication by having informal meetings whenever possible, forming teams across functions, and planning the physical layout of the facility so as to encourage frequent interaction (Harrison and Enz, 2005). Higher levels of excellence, competitive advantage, and profitability can only be accomplished when existing innovations are implemented, retained, and improved. Routinization is an important final step in championing new ideas, and true innovators need to be sure that their excellent ideas have staying power. Success in the introduction of a best practice occurs only when the practice becomes incorporated into the regular activities of the organization and loses its separate identity.

Organizations must commit resources such as people, money, information, equipment, and a physical location for innovations to take hold (Normann, 1971). Giving people time to pursue their ideas is critical, however effective rewards systems can speed the process of change. Innovative firms allow creative people to realize the rewards from their innovative talents without having to leave the company (DeCarolis and Deeds, 1999). Innovation should be rewarded through raises, promotions, awards, perquisites, and public and private recognition. While the upside rewards for innovation should be high, the downside penalties for failed innovation efforts should be minimal.

The findings on innovation in the hospitality industry reinforce the importance of operational integration, and the need to build organizational learning capacity. Hotel companies and individual properties can gain a competitive advantage only if they are able to integrate and apply innovations in day-to-day operations (Enz and Siguaw, 2003). From selfmanaged housekeeping teams to recycling programs, successful execution of innovations requires top-management support, the involvement of employees, and strong organizational communication. Sadly innovation appears to be one of the casualties of the significant consolidation in the lodging industry. This view is consistent with earlier authors who argued that the standardization built into large hospitality chain operations serves to stifle innovation (Peacock, 1993; Morrison and Thomas, 1999). Not all large organizations lack innovativeness. Corporate entrepreneurship, sometimes called intrapreneurship, corporate venturing, or corporate enterprise 
involves the creation of new products, processes, and services within existing corporations that enable them to grow (Pinchot, 1985). While there is some debate on the concept of corporate entrepreneurship, it does appear to enhance the performance of large organizations (Pittaway, 2001). For example existing restaurants have begun offering new menu items at an accelerating rate (up 31.6\% since the mid 1990s), although competition and the ease of imitation has made these product innovations short-lived (Yee, 2001). Some argue that small companies tend to be better than large companies at innovation. One reason for the difference is that smaller companies are more flexible. They are not subject to the constraints of a rigid bureaucracy that can stifle creative activity. Indeed much of the literature on entrepreneurship has revealed that they possess a greater ability to innovate (Stewart, 1998). In studies within hospitality firms small firm marketing efforts were found to be more dynamic, distinctive, and thus more innovative. Others have found entrepreneurs to be more innovative than managers in large firms (Buttner and Gryskiewicz, 1993). We now turn to a discussion of entrepreneurship to more fully understand this unique group of innovators.

\section{ENTREPRENEURSHIP}

Would-be entrepreneurs live in a sea of dreams. Their destinations are private islands - places to build, create, and transform their particular dreams into reality. Being an entrepreneur entails envisioning your island, and, even more important, it means getting in the boat and rowing to your island

(Shefsky, 1994: 10).

\section{Entrepreneurial start-ups}

The history of the hospitality industry is a story of entrepreneurship. In the broadest sense of the term, entrepreneurship is the creation of new business. It involves opportunity recognition or creation, assembling resources to pursue the opportunity, and managing activities that bring a new venture into existence. Some ventures are complete start-ups, while other ventures are pursued within an existing organization. According to Arnold Cooper, widely acknowledged as a pioneer in the study of entrepreneurship, 'Entrepreneurial ventures, whether independent or within established corporations, might be viewed as experiments. They test to determine the size of particular markets or whether particular technologies 
or ways of competing are promising. They have good internal communication and enormous commitment from their key people' (McCarthy and NichollsNixon, 2001:29).

Hundreds of thousands of small firms are created each year. In the United States more than 1 million new jobs across a range of industries are created annually by these firms, while Fortune 500 companies are cutting their workforces. A recent study reported a surge in new business start-ups in the United States with women, minorities and baby boomers leading the growth in new venture formation. In fact since 1990 the number of entrepreneurs over the age of 50 has increased by $23 \%$ to 5.6 million workers according to the American Society of Training and Development (2005). Eating and drinking places in America are mostly small businesses, with more than half being sole proprietorships or partnerships (Milton, 2003). More than half of the private workforce is employed in firms with fewer than 500 employees. These businesses account for about half of the private- sector gross domestic product. Interestingly, two-thirds of new inventions come out of smaller firms (Reynolds et al., 1999). Nevertheless, entrepreneurship is a high-risk activity. Entrepreneurs in nations with highly developed economies often complain about how difficult it is to keep a new business going, and they are right. However, entrepreneurial efforts in less-developed economies such as Russia are even more difficult: 'An unstable government, an undeveloped legal system, overregulation, a virtually unfathomable taxation system, a pervasive mafia, and an inadequate business structure characterize the maze that Russian entrepreneurs must navigate in their attempts to create successful ventures' (Puffer and McCarthy, 2001: 24).

\section{The entrepreneur}

Entrepreneurs have been studied for many years, and lists of their characteristics are numerous (Brockhaus, 1980; Gartner, 1989; Hay et al., 1990; Lumpkin and Dess, 1996). Research seeking to identify the specific traits that distinguish entrepreneurs from those who do not start new businesses has been inconclusive; however some evidence exists to suggest that entrepreneurs have a higher need for achievement, a greater risk-taking propensity, and greater internalized locus of control (Wooten et al., 1998). In one study that focused on a battery of personality tests only aggressiveness was a significant predictor of new business starters (Wooten et al., 1998).

Turning to the literature that examines hospitality entrepreneurs, one common characterization used by researchers is the 'craft' versus 
'opportunistic' entrepreneur. While 'craft' entrepreneurs are characterized as blue-collar, working-class, with low education and paternalistic management styles, the 'opportunistic' hotelier is defined as middle class with higher levels of education and professional management styles. An early study by Hankinson (1990) found that small hoteliers were just trying to survive, relying on price competition and little marketing, hence more ' $c r a f t$ ' like. In contrast more recent work has found that the 'opportunistic' entrepreneur is more likely the case in small hotel proprietors. A close look at entrepreneurs in the small hotel sector in Scotland revealed that those who survive actively pursue rational business objectives and employ marketing strategy to achieve those objectives (Glancey and Pettigrew, 1997). In short, successful entrepreneurs appear to be opportunists, in that they recognize and take advantage of opportunities. Kemmons Wilson founded Holiday Inn in 1952 after a family vacation the previous year in which he became annoyed at the \$2-per-child surcharge attached to his bill for each of his five children. He saw the opportunity for a new concept and introduced a chain of hotels that defined the modem hotel era with amenities we now take for granted, such as kids stay for free, air conditioning in every room, free parking, free ice, in-room phones, rates by the room and not the number of people, and high cleanliness standards (Brewster, 2004). Entrepreneurs are also resourceful, creative, visionary, hardworking, and optimistic. Conrad Hilton got his start in the lodging industry by renting out rooms in his home in New Mexico. They are independent thinkers who are willing to take risks and innovate. They also tend to be excellent leaders (Min, 1999). Above all, they are dreamers. Everyone around her thought Debbi Fields would fail when she decided to start selling her delicious cookies. She founded Mrs. Fields' Original Cookies, a company with over $\$ 100$ million in sales and over 4,000 employees. Unfortunately these common characteristics may seem quaint and the examples simplistic, but they do suggest that there may be several key characteristics that individuals may need to possess in order to succeed in starting their own businesses. More research is needed on the effects of hospitality entrepreneurs' personality in shaping and growing new business startups. Future research should consider whether personality influences entrepreneurship in hospitality and in what ways. A more comprehensive and thoughtful understanding of key characteristics can be particularly helpful in guiding students to career choices. We now turn to the major activities associated with new business start-ups.

\section{The key entrepreneurial tasks}

The primary tasks associated with a new venture are recognition or 
creation of an opportunity, creation of a business plan, securing start-up capital and actual management of the start-up through its early stages. Entrepreneurship is often envisioned as a discovery process that entails channeling resources toward the fulfillment of a market need (Jackobson, 1992). For a start-up to be successful, this often means meeting a need better than other companies Take for example the efforts of Kapil Grove and his father who developed in the early 1980s wines that complemented traditionally spicy Indian cuisine. Grover Vineyards, the business that emerged from this idea was based on experimenting with different types of French grapes and Indian growing conditions and consumer tastes. This business became a joint venture with Veuve Clicquot, a brand of Paris- based luxury goods giant LVMH Moet Hennessy Louis Vuitton SA, only after the Grove family took on the challenge of creating a market where none had previously existed (Parmar, 2002). As this example illustrates, entrepreneurial discovery may be viewed as the intersection of a need and a solution. Entrepreneurial activity occurs anytime an entrepreneur is able to link a need to a solution in such a manner that a new business emerges.

Everything associated with a new venture revolves around a business plan. Creation of the plan forces the entrepreneur to think through the details of the venture and determine whether it really seems reasonable. Investors are also interested in what might be called an 'endgame' strategy. This is a plan for concluding the venture, transferring control to others, or allowing potential investors to exit the venture with a high return on their investments. It may also include contingency plans in the event the venture does not succeed (i.e. alternative uses or sales potential for acquired resources), and an executive-succession plan in case the primary entrepreneur decides to leave the venture. Finally, potential investors will be very interested in the amount of risk found in a venture.

Obtaining start-up capital is probably the most difficult problem facing a potential entrepreneur, and not obtaining sufficient capital is one of the biggest causes of failure. Some of the most common sources of start-up capital include commercial banks, personal contacts, venture capitalists, corporate partnerships, investment groups and business angels. Bank loans result in debt. Personal contacts may be among the most flexible sources of financing because the financiers have a personal interest in the entrepreneur. In the early years of the gaming business in Las Vegas, for example, most of the funding came from the Teamsters' Central States Pension Fund because financial institutions steered away from casino investments (Lalli, 1997). Venture capitalists, corporate partners, investment groups and business angels may provide loans, receive equity, or own part or 
all of the property in exchange for the capital they provide.

Some entrepreneurs are able to start with their own financial resources. For example, the first of Colonel Sanders' fried-chicken restaurants was financed with his social security (i.e. government retirement) check (Shefsky, 1994). Anne Beiler of Auntie Anne's, Inc. began her first pretzel stand with a $\$ 6,000$ loan from her in-laws. For larger ventures or once these resources are exhausted, entrepreneurs often turn to a bank. Because of the risks involved, commercial banks do not tend to get very excited about financing entrepreneurial ventures unless substantial secured assets are involved. For example, entrepreneurs often mortgage their homes or offer their automobiles, jewelry, or financial investments as loan security. Banks also consider loans more attractive if a wealthy third party is willing to co-sign, thus taking on the financial obligation if the entrepreneur is unable to pay. Occasionally, a bank will make an unsecured loan based on the reputation or credentials of the entrepreneur or on a personal relationship. Restaurants are often considered a bad investment by bankers who will refuse to finance these ventures because of the low barriers to entry, little collateral value in used restaurant equipment, and the long hours required on-site by owners (Rainsford and Bangs, 1992).

Venture capitalists are another potential source of start-up capital. They are individuals or groups of investors that seek out and provide capital to entrepreneurs with ideas that seem to have the potential for very high returns. Retail and service businesses began to receive more attention from the venture community in the 1990s, although they typically do not get involved in restaurant investments unless they are larger and more established multi-unit operations. They may seek an annual return as high as $60 \%$ or more on 'seed money' for a new venture (Schilit, 1987). In addition, recent research has found that venture capital involvement can have negative consequences for wealth formation of the entrepreneur. In one study founders who rely on high levels of venture capital were worse off financially two years after their businesses engaged in a public offering (IPO) and were more likely to be fired from their firms (Florin, 2005). Financing from a venture capitalist is often combined with capital from other sources such as banks or private investors. In the restaurant industry venture capitalists often wait till later stages in the company's life cycle to provide capital. The most common first disbursement is usually provided to companies that are about to expand (called third-stage or mezzanine financing) rather than to provide start-up financing to develop an initial unit (Hudson, 1999). The House of Blues, a restaurant and nightclub concept used three venture capital firms: Aeneas Group, US Venture Partners, and the 
Platinum Group to help finance the building of new units and a merchandising operation (Waddell, 2004).

The restaurant industry has many advantages as an investment target including its fragmented nature with good growth potential, low risk of obsolescence in products, and the potential for mass distribution. Considering the use of venture capital can also benefit the entrepreneur because of access to large amounts of capital and the ability to obtain management expertise and advice to refine and sustain the start-up (Hudson, 1999). Entrepreneurs may also turn to corporations to obtain financing. From the entrepreneur's perspective, the chief disadvantage of this form of financing is a partial loss of control and ownership. Large corporations often seek investments in new ventures as a way to obtain new technology, products, or markets. Another potential source of capital is business angels, wealthy individuals who provide start-up capital to entrepreneurs with promise. Many of them were once entrepreneurs themselves. They sometimes seek high returns, but many of them enjoy investing simply for the sake of helping an entrepreneur or advancing the state of technology in an area such as medicine, the arts, or computer technology. Unlike venture capitalists, business angels do not pursue investing full-time.

\section{Why entrepreneurs fail}

The early stages of an entrepreneurial start-up are the most difficult (Terpestra and Olson, 1993). Fundamental concerns for entrepreneurs are adequate capital and managing cash flow. Many new ventures fail because of a lack of capitalization. Entrepreneurs often experience cash flow problems because occupancy rates and other cash flows typically take a while to materialize. Low sales can plague a new venture, especially in the first few months after introduction. Many consumers and businesses wait to see if the new restaurant or hotel receives good reviews. They look for a 'track record'. Without sufficient capital, the venture may fail even if the idea was good and the management skills were present. For example, a business may need to be a particular size to generate enough efficiency to make a profit. Or a venture may fail because not enough people know about a product or service due to insufficient advertising. A firm that does not initially have enough financial backing may also assume too much debt too early. Interest payments can divert funds away from more-important uses, and the risk of insolvency from not being able to make timely payments is a constant threat. When entrepreneurs feel high levels of financial risk, their behavior may 
change. They may be less willing to take other risks that are necessary for the venture to continue to progress.

Even after the process of securing initial financing, the entrepreneur must still set up a system to manage financial flows and keep records necessary to satisfy venture capitalists, creditors, and governmental institutions.

Another common challenge for hospitality entrepreneurs is devising an effective service delivery system. Entrepreneurs seldom get a service exactly right from the outset. Early consumers will very quickly discover flaws, and setting up a system that collects feedback from early customers can help improve service. Theme restaurants, like the once bankrupt Planet Hollywood, suffered from low profitability because of the high wages of their entertainers, inflated prices, stagnant menus and the lack of repeat customers (Campbell, 2000). Continuous improvement is essential because if the product or service is a success, other firms will quickly imitate it, particularly larger firms with more resources. Therefore, it is important to stay one step ahead of the competition in order to enjoy first-mover advantages. It is interesting to note that most entrepreneurs do not feel that competitors are much of a problem. This point attests to the advantages of being small and introducing a new product or service to the market, and the risk-taking characteristic of entrepreneurs.

Even if a venture has sufficient capitalization, and a good service delivery system, it can still fail if market conditions are not favorable. This is a timing issue. An entrepreneur may begin the launch of a new hotel or restaurant right before a downturn in the domestic economy or in a foreign economy upon which the new venture is dependent. Tourism is an industry that is extremely vulnerable to localized recessions and seasonal demand. For example, some expatriate- owned bars and cafes are so focused that they depend on particular nationalities within the already niche tourism market for their success (Blackwood and Mowl, 2000). In these instances sudden and unpredictable changes in consumer demand can be fatal. The language barrier and ignorance of local customs and regulations can also be sources of failure for expatriates running small businesses. From an owners' perspective, a variety of factors appear critical to successful hospitality ventures in mass tourist destinations including: access to sufficient capital, sound planning, effective financial management, management experience, industry experience, business training, use of external advisors, and oversees experience (Blackwood and Mowl, 2000). Management experience may be the most important factor when exploring new venture failure. 
According to both entrepreneurs and venture capitalists, the number-one reason new ventures fail is lack of management skill (Zacharakis et al., 1999). Entrepreneurs often have enthusiasm, optimism, and drive, but do not possess the business skills they need to make a venture successful.

Management problems are also experienced with inventory control, facilities and equipment, human resources, leadership, organization structure, and accounting systems. The low barriers to entry in the hospitality industry make it possible for inefficient operators lacking skill and experience to enter the industry (English et al., 1996). According to Dun and Bradstreet's 'Business Failure Record', the retail sector, which includes the restaurant industry, and the service sector, which captures the lodging industry, experiences the highest business failures. In addition, within the retail sector, that includes food stores, and general merchandise stores along with other types of businesses, the eating and drinking places have more business failures than any other single industry (Gu and Gao, 2000). Although experts, executives, and the investment community estimate restaurant failure rates as high as $90 \%$ in the United States and West European cities, recent research has found failures to run about $30 \%$ in the first year of operations (Hubbard, 2003; Parsa et al., 2005).

For some entrepreneurs the benefit of brand recognition, economies of scale, training, access to a reservation system, and marketing support make franchising a viable approach to business ownership. In addition, chain affiliation often gives hotel developers an edge with lending institutions (Graves, 2003). Of particular concern to many entrepreneurs in recent years are the highly variable reports on the failure rate of franchise operations. The US Federal Trade Commission's consumer protection director notes, 'The most widespread myth is that franchises are a safe investment because they have a much lower failure rate than independent business. In fact, there may be much less of a difference than is commonly thought' (Oleck, 1993: 91). We now turn to a brief discussion of franchising.

\section{Franchising}

In the United States, lodging industry franchising is a viable way to start a new venture with around $70 \%$ of hotels affiliated with a chain, although this percentage is substantially lower in other parts of the world. Franchising is also popular in the restaurant industry, with the greatest number of franchised concepts being in the fast-food industry (Milton, 2003). Defining new market niches and developing new operating systems are two ways in which franchisors foster innovation (Kaufman and Dant, 1998; Combs et al., 
2004). Franchising is when two independent companies form a contractual agreement giving one (the franchisee) the right to operate a business in a given location for a specified period of time under the other firm's (franchisor) brand. Franchisees agree to give the franchisor a combination of fees and royalties usually in the form of a percentage of unit sales in restaurants or a percentage of room sales in hotels. Also included in these agreements are an advertising contribution paid to the franchisor as a percentage of unit revenues. Hospitality firms engage in what is called business-format franchising, which is when the franchisor sells a way of doing business to its franchisees. This form of franchising is in contrast to traditional franchising in which the franchisor is mostly a manufacturer selling its product through a franchise network such as car dealerships (Lafontaine, 1999).

In addition to helping create new businesses in a home country, franchising has historically been an important tool for international expansion. International franchising is an extremely profitable tool to accomplish branding and growth. In the beginning, the first to export a business-format franchise model to markets outside of the US were fast-food franchise powerhouses such as McDonald's and Kentucky Fried Chicken of parent company YUM! Brands (Polly, 2002). Now these pioneers of international franchising are as common in many other countries as they are in the United States, and they have been joined by other food concepts, hotels and most of the major players in all industries that franchise. However, franchising is a lower return strategy compared with equity investments in hotels abroad (Contractor and Kundu, 1998).

A franchise strategy may be more difficult outside of North America because of the lack of infrastructure in some countries. Finding franchisees with good sites to build on is also a challenge in light of regulations restricting hotel property development in Europe and other parts of the world (Cruz, 1998). A certain level of learning skill or absorptive capacity is required of a franchisee to adopt the business concept in the overseas location; hence studies in hotel franchising have shown that franchising is more likely in developed nations because of the greater likelihood that the global partners possess the needed organizational skills (Contractor and Kundu, 1998). To help deal with the challenges of developing internationally sometimes chains develop master franchisees as partners. Master franchise agreements involve larger franchisees who have the rights to develop in a specific territory. Cendant, for example, continues to expand through master licenses. In contrast, Marriott does not master franchise as much, and not at all with their Ritz-Carlton brand. Markets dictate whether franchising is used, 
for example, Marriott relies on franchising in Moscow and has a master franchise agreement with Whitbread in the UK. Often times a master franchise is used in non-strategic or smaller markets.

From the perspective of the franchisee, these business deals are often used to reduce the risks association with new business formation (Combs et al., 2004). Is franchising less risky than going into business on one's own? While conventional wisdom might say yes, current research suggests that joining a new and small franchise may be more risky than starting one's own business because success depends on the capacity of the franchisor and the other few franchisees to make the entire chain work. The likelihood of failure is lower when one joins an established chain with many units such as Subway, Pizza Hut, Applebee's Neighborhood Grill and Bar, Panera Bread Company, or Red Lobster. It is important to understand that franchising is not without risks, with one study showing that less than $25 \%$ of companies that offered franchises in the USA in 1983 were still franchising ten years later (Lafontaine, 1999).

An entrepreneur considering franchising as their method of doing business needs to keep in mind that multi-unit franchisee ownership is common in the hospitality industry; for example the average McDonald's franchisee in the USA owns three restaurants. The multi-unit franchisee will have far more bargaining power in their transactions with the franchisor, and hence the new entrepreneur needs to consider their own long-term ownership strategy. Further, a study of quick-service restaurant franchise systems found that growth was faster for chains with a greater proportion of multi-unit franchisees (Kaufman and Dant, 1998). Franchising can be very promising although there will always be opportunities for entrepreneurs who operate independent hotels or restaurant, in which they can reap substantial storelevel profits and leverage prime locations and distinctive service features.

\section{CONCLUSION - FUTURE DIRECTIONS}

This chapter has examined hospitality innovation and entrepreneurship by defining and exploring how to foster innovation and summarizing the key characteristics of new business formation. In an industry that has historically relied on entrepreneurs and franchising business models, several fruitful areas of future study remain. One promising area for future research is the link between the personal characteristics of the entrepreneur and the strategies they choose. An entrepreneur's past history and personal issues may pervade if not profoundly shape the direction of a new firm and its 
organizational functioning. A recent study of a family firm found that founder life issues were strongly reflected in strategic priorities (Kisfalvia, 2002). Within the area of franchising, further study of multi-unit franchisees could be a fascinating new area as many firms engage in transnational strategies. In what ways do multi-unit franchisees shape franchisor direction setting and corporate performance? As firms like Starbucks continue their international expansion how do master franchisees help or hinder global expansion?

The troubling findings reported on hotel innovation sustainability and the role of the single idea champion suggests that efforts to craft and sustain an innovation-orientation in the firm may be essential for strategic flexibility and renewal. When idea champions in hotel companies are unable to sustain their innovations it suggests that the industry needs to invest more in the building of a dominant logic that leads to the support of entrepreneurial actions and capabilities. In the complex, uncertain and global world of hospitality successful firms will be those that are able to continuously innovate and encourage entrepreneurship at all levels. There is still much we do not know about innovation and entrepreneurship in hospitality, and hence many promising areas for future study. 


\section{REFERENCES}

American Society of Training and Development. (1995) 'US SelfEmployment rising, says small, business administration,' Training and Development 59(9): 19.

Amit, R. and Zott, C. (2001) 'Value creation in E-business,' Strategic Management Journal, 22: 493-520.

Blackwood, T. and Mowl, G. (2000) 'Expatriate-owned small businesses: measuring and accounting for success,' International Small Business Journal, 18(3): 60-73.

Brewster, M. (2004) 'Kemmons Wilson: America's innkeeper,' Business Week Online, 10/13/2004.

Brockhaus, R. (1980) 'Risk taking propensity of entrepreneurs,' Academy of Management Journal, 23: 509-520.

Business World. (2002) 'Innovation key to success,' October 31, 2002.

Buttner, E. H. and Gryskiewicz, N. (1993) 'Entrepreneurs' problem-solving styles: an empirical study using the Kirton adaptation/innovation theory,' Journal of Small Business Management, 31(1): 22-31.

Campbell, S. (2000) 'Prosperity bodes well for the hospitality industry in the new millennium,' The Black Collegian, 30(2): 6875.

Combs, J., Ketchen, D. and Hoover, V. (2004) 'A strategic groups approach to the franchising-performance relationship,' Journal of Business Venturing, 19(6): 877-897.

Conley, C. (2001) The Rebel Rules: Daring To Be Yourself in Business. New York: Fireside Book. 
Contractor, F. and Kundu, S. (1998) 'Franchising versus companyrun operations: modal choice in the global hotel sector,' Journal of International Marketing, 28-53.

Cruz, T. (1998) 'Speed to market,' Hotels, 32(2): 40.

DeCarolis, D. M. and Deeds, D. L. (1999) 'The impact of stocks and flows of organizational knowledge on firm performance,' Strategic Management Journal, 20: 953-968.

Drucker, P. F. (1999) 'Beyond the information revolution,' Atlantic Monthly, October: 47-57.

Dube, L., Enz, C., Renaghan, L. and Siguaw, J. (2001) American Lodging Excellence: The Keys to Best Practices in the US Lodging Industry. Washington, DC: American Hotel Foundation.

English, W., Josiam, B., Upschurch, R. and Willems, J. (1996) 'Restaurant attrition: a longitudinal analysis of restaurant failures,' International Journal of Contemporary Hospitality Management, 8(2): 17-20.

Enz, C. (2005) 'The heavenly Bed, Could This Be An Innovation? Case Study Prepared for Student Use,' USA Today, Fall 2004.

Enz, C. (2003) 'Hotel pricing in a networked world,' Cornell Hotel and Restaurant Administration Quarterly, 44(1): 4-5.

Enz, C. and Siguaw, J. (2003) 'Revisiting the best of the best: innovations in hotel practice', Cornell Hotel and Restaurant Administration Quarterly, 44(6)

Florin, J. (2005) 'Is venture capital worth it? Effects on firm performance and founder returns,' Journal of Business Venturing, 20(1): 1 13-135.

Gartner, W. (1989) 'Some suggestions for research on entrepreneurial traits and characteristics,' Entrepreneurship 
German, R. and Muralidharan, R. (2001) 'The three phases of value creation,' Strategy and Business, 22(1): 82-91.

Graves, T. (2003) 'Industry surveys - lodging and gaming,' in Standard and Poor's, 16.

Green, P. G., Brush, C. G. and Hart, M. M. (1999) 'The corporate venture champion: a resource-based approach to role and process,' Entrepreneurship Theory and Practice, March: 103-122.

Grimm, C. and Smith, K. (1999) Strategy as Action: Industry Rivalry and Coordination. Cincinnati, $\mathrm{OH}$ : Southwestern.

Gu, 2. and Gao, L. (2000) 'A multivariate model for predicting business failures of hospitality firms,' Tourism and Hospitality Research, (2)1: 37-49.

Guadalupe-Figaro, E. (2001) 'Westin And W brands introduce retail catalogue to sell heavenly bed and in-room, trendsetting items,' Caribbean Business, 01948326, 2/1/2001, Vol. 29, Issue 4.

Hamel, G. (2000) Leading the Revolution. Boston, MA: Harvard Business School Press.

Hamel, G. (2001) 'Is this all you can build with the Net? Think bigger,' Fortune, April: 134-138.

Harrison, J. and Enz, C. (2005) Hospitality Strategic Management: Concepts and Cases. Hoboken, NJ: John Wiley and Sons, Inc.

Hay, R. T., Kash and Carpenter, K. (1990) 'The role of locus of control in entrepreneurial development and success,' Journal of Business and Entrepreneurship, 2: 13-22.

Hospitality Design (1999) 'Sleep study a design wakeup call for Westin,' Hospitality Design, Nov/Dec. 1999, Vol. 21, Issue 8. 
Hubbard, H. (2003) 'Putting your money where your mouth is restaurants: howto spot a hot investment,' International Herald Tribune, January 11:13.

Hudson, B. (1995) 'Venture capital in the restaurant industry,' Cornell Hotel and Restaurant Administration Quarterly, 36: 50-61.

Kaufmann, P. J. and Dant, R P. (1996) 'Multi-unit franchising: growth and management issues,' Journal of Business Venturing, 11(6): 343-358.

Kisfalvi, V. (2002) 'The entrepreneur's character, life issues, and strategy making: a field study,' Journal of Business Venturing, 17: 489-518.

Kuratko, D. F. and Hodgetts, R. M. (2001) Entrepreneur- ship: A Contemporary Approach, 5th edn. Fort Worth, Texas: Harcourt College Publishers.

Lafontaine, F. (1999) 'Survey-Mastering Strategy: 9 Myths and Strengths of Franchising,' Financial Times, November 22:10.

Lalli, S. (1997) 'A peculiar institution.' In J. Sheehan (ed.) The Players: The Men Who Made Las Vegas. Reno/Las Vegas: University of Nevada Press, pp. 1-22.

Lumpkin, G. and Dess, G. (1996) 'Clarifying the entrepreneurial orientation construct and linking it to performance,' Academy of Management Review, 21: 135-172.

McCarthy, A. M. and C. L. Nicholls-Nixon (2001) 'Fresh Starts: Arnold Cooper on entrepreneurship and wealth creation,' Academy of Management Executive 15: 29.

McGrath, R. and MacMillan, I. C. (2000) The Entrepreneurial Mindset. Boston, MA: Harvard Business School Press.

Milton, D. (2003) 'Industry surveys restaurants,' Standard and 
Min, S. J. (1999) 'Made not born,' Entrepreneur of the Year Magazine, Fall: 80.

Morrison, A. and Thomas, R. (1999) 'The future of small firms in the hospitality industry,' International Journal of Contemporary Hospitality, 11(4): 148-146.

Naisbitt and Aburdene (1985) Re-inventing the Corporation.

'National Commission to Ensure Consumer Information and Choice in the Airline Industry, 'Upheaval in Travel Distribution: Impact on Consumers and Travel Agents (November 12, 2002).

Normann, R. (1971) 'Organizational innovativeness: product variation and reorientation, ' Administrative Science Quarterly, 16: 203-215.

Oleck, J. (1993) 'The numbers game: failure-rate statistics run the gamut, but whose are right?', Restaurant Business, 86 (June 10): 91.

Parmar, A. (2002) 'Exposure wins Indian Vintner favor', Marketing News, 6. October 28, 2002.

Peacock, M. (1993) 'A question of size,' International Journal of Contemporary Hospitality, 5(4): 29-32.

Pearce, J. A., II, Kramer, T. R. and Robbins, D. K. (1997) 'Effects of managers' entrepreneurial behavior on subordinates,' Journal of Business Venturing, 12: 147-160.

Pittaway, L. (2001) 'Corporate enterprise: a new reality for hospitality organizations?', International Journal of Hospitality Management, 20: 379-393.

Polly, L. (2003) 'International growth patterns remain strong,' 
Puffer, S. M. and McCarthy, D. J. (2001) 'Navigating the Hostile Maze: a framework for Russian entrepreneurship,' Academy of Management Executive, November: 24.

Quinn, J. B. (1985) 'Managing innovation: controlled chaos,' Harvard Business Review, May/June: 73-84.

Rainsford, P. and Bangs, D. (1992) The Restaurant Planning Guide: Starting and Managing a

Successful Restaurant. Dover, NH: Upstart Publishing Company.

Restaurant Business (2002): 'McDonalds set to unveil new format,'June: 11.

Reynolds, P. D, Hay, M. and Michael Camp, S. (1999) Global Entrepreneurship Monitor (Kauffman Center for Entrepreneurial Leadership).

Roberts, P. (1999) 'Product innovation, product-market competition and persistent profitability in the US pharmaceutical industry, ' Strategic Management Journal, 20(7): 655-670.

Schilit, W. K. (1987) 'How to obtain venture capital,' Business Horizons, May/June, 78.

Schoenberger, C. R. (2004) 'Room for rent - or sale,' Forbes, 6/7/2004, Vol. 173(12).

Schumpeter, J. (1934) The Theory of Economic Development. Cambridge, MA: Harvard University Press.

Sheehan, P. (2001) 'Back to bed,' Lodging Hospitality, 57(4). 
Siguaw, J., Simpson, P. and Enz, C. (2006) 'Conceptualizing innovation orientation: a framework for study and integration of innovation research,' Journal of Product Innovation Management, 23: 556-574.

Sivadas, E. and Dwyer, F. R. (2000) 'An examination of organizational factors influencing new product success in internal and alliance-based processes', Journal of Marketing, 64(1): 31-49.

Subramaniam, M. and Venkatraman, N. (1999) 'The influence of leveraging tacit overseas knowledge for global new product development capability: an empirical examination. In M. Hitt, P. Clifford, R. Nixon and K. Coyne (eds) Dynamic Strategic Resources. Chichester: Wiley, pp. 373-401.

Terpestra, D. E. and Olson, P. D. (1993) 'Entrepreneurial start-up and growth: a classification of problems,' Entrepreneurship Theory and Practice, 19 (Spring).

Van de Ven, A., Polley, D., Garud, R. and Venkataraman, S. (1999) The Innovation Journey. New York: Oxford University Press.

Waddell, R. (2004) 'HOB sets sights on growth armed with fresh funding,' Billboard, 116(14): 10.

Walsh, K., Enz, C. and Siguaw, J. (2003) 'Innovations in hospitality human resources: cases from the US lodging industry.' In Kasluvan, Salih (ed.) Managing Employee Attitudes and Behaviors in the Tourism and Hospitality Industry. New York: Nova Science Publisher.

Wooten, K., Timmerman, T.A. and Folger, R. (1998) 'The use of personality and the five-factor model to predict new business ventures: from outplacement to start-up,' Journal of Vocational Behavior, 54: 82-101. 
the menu,' Restaurants and Institutions, July 15, 2001.

Zacharakis, L., Meyer, G. D. and DeCastro, J. (1999) 'Differing perceptions of new venture failure: a matched exploratory study of venture capitalists and entrepreneurs,' Journal of Small Business Management, July: 1-14. 